\title{
Factors affecting the determination of iron species in the presence of ferric iron
}

\author{
Jian Zhu ${ }^{1} \cdot \mathrm{Xi} \mathrm{Yang}^{1} \cdot$ Feifei Fan ${ }^{2} \cdot$ Yitong $\mathrm{Li}^{1}$ \\ Received: 16 February 2018 / Accepted: 7 November 2018 / Published online: 16 November 2018 \\ (c) The Author(s) 2018
}

\begin{abstract}
The high concentration $\mathrm{Fe}^{3+}$ in sample had interference on the determination of iron species by spectrophotometric method in which 1,10-phenanthroline was used to as a chromogenic agent. The $\mathrm{F}^{-}$could mask absolutely the effect of $\mathrm{Fe}^{3+}$ when $\mathrm{F}^{-} /$ $\mathrm{Fe}^{3+}$ molar concentration ratio was 13.3. The temperature or light did not affect the masking action of $\mathrm{F}^{-}$. Low temperature and dark conditions favored the stability of chromophoric complex. This method is suitable for the measure of iron species where the concentration of $\mathrm{Fe}^{3+}$ is far more than that of $\mathrm{Fe}^{2+}$ in samples.
\end{abstract}

Keywords Iron species $\cdot$ Spectrophotometric $\cdot$ Fluorine ion $\cdot$ Masking action $\cdot$ Storage condition

\section{Introduction}

Acid mine drainage (AMD) is produced when sulfide minerals are exposed to oxic conditions. AMD distributes widely around the world, like USA (Nordstrom et al. 2000), South Africa (Tutu et al. 2008), Australia (Webb and Sasowsky 1994), Ireland (Gray 1998) and China (Wu et al. 2009). AMD is characterized by low $\mathrm{pH}$ values (Blowes et al. 2003; Nordstrom et al. 2000), high iron concentration and various heavy metals (As, $\mathrm{Hg}$, Sb et al.) (Arnold et al. 2011; Iakovleva et al. 2015). Iron species and contents can affect the transport and transformation of heavy metals (Matlock et al. 2002; Zhu et al. 2017). So, it is important to exactly determine iron species in the investigation of environmental behavior of heavy metals in AMD.

The spectrophotometric methods have been commonly used for the analysis of iron content such as 2,2'-bipyridyl and 2,2',2"-terpyridyl 4,7-diphenyl-1 method (Moss and Mellon 1942), 4,7-diphenyl-1,10-phenanthroline method (Clark 1962), ferrozine method (Herrera et al. 1989) and 1,10-phenanthroline method (Tamura et al. 1974). The 1,10-phenanthroline method is used widely due to its high

Jian Zhu

zhujian2009@126.com

1 College of Resource and Environmental Engineering, Guizhou University, Guiyang, People's Republic of China

2 Guizhou Institute of Soil and Fertilizer, Guiyang, People's Republic of China sensitivity (Tong et al. 2016; Amonette and Matyáš 2016; Sumitomo et al. 2017). The high concentration $\mathrm{Fe}^{3+}$ affects the analysis of $\mathrm{Fe}^{2+}$ in the process of colorimetry by the 1,10-phenanthroline method such as AMD samples, so $\mathrm{F}^{-}$is added into the solution to eliminate interferences (Herrera et al. 1989). The $\mathrm{F}^{-}$reacts with $\mathrm{Fe}^{3+}$ to form ferric fluoride which does not react with 1,10-phenanthroline, so $\mathrm{F}^{-}$was a complexing agent to modify the 1,10-phenanthroline method (Herrera et al. 1989). The studies on the usage rules of $\mathrm{F}^{-}$and reaction conditions of chromophoric complexes by the 1,10-phenanthroline method are few. Besides, the stability of chromophoric complexes under different temperatures or lights is not known.

The objectives of this study were to investigate the effects of $\mathrm{Fe}^{3+}$, obtain a suitable dosage of $\mathrm{F}^{-}$which can mask the interference of $\mathrm{Fe}^{3+}$ and assess the effects of light, reaction temperature and time. And then, the solutions after chromogenesis were stored under different conditions to evaluate the stability of chromophoric complex.

\section{Materials and methods}

\section{Chemicals}

Ferrous sulfate $(99.9 \%)$, ferric chloride $(99.9 \%)$, sodium fluoride $(99.9 \%)$, ammonium acetate $(99.9 \%)$, acetic acid (99.9\%) and 1,10-phenanthroline (99.9\%) were purchased from Sinopharm Chemical Reagent Co. Ltd, China. The 
deionized water prepared by a Milli-Q water purification device (Millipore, USA) was used in all experiments.

\section{Batch experiments}

Different amounts of $400 \mathrm{mg} / \mathrm{L} \mathrm{Fe}^{3+}$ and $100 \mathrm{mg} / \mathrm{L} \mathrm{Fe}^{2+}$ solutions were added to deionized water to produce modified AMD. In modified AMD, the molar ratios of $\mathrm{Fe}^{3+} / \mathrm{Fe}^{2+}$ were $0,0.1,0.5,1,2,4,8,16$, respectively. These samples were used to assess the interferences of $\mathrm{Fe}^{3+}$ on the measurement of $\mathrm{Fe}^{2+}$.

To obtain appropriate fluorine ion $\left(\mathrm{F}^{-}\right)$concentration to mask $\mathrm{Fe}^{3+}$, different amounts of $\mathrm{F}^{-}$were added into modified AMD which contains $2 \mathrm{mg} / \mathrm{L} \mathrm{Fe}^{2+}$ and $8 \mathrm{mg} / \mathrm{L} \mathrm{Fe}^{3+}$ to make $\mathrm{F}^{-} / \mathrm{Fe}^{3+}$ molar concentration ratio be $0,1,2,4,6,8$, $12,18,36$, respectively. To evaluate the influence of temperature on chromogenic reaction, chromogenic reaction has been performed under 5,15 or $30{ }^{\circ} \mathrm{C}$, respectively, where solutions contained $2 \mathrm{mg} / \mathrm{L} \mathrm{Fe}^{2+}, 8 \mathrm{mg} / \mathrm{L} \mathrm{Fe}^{3+}$ and with or without the addition of $36.1 \mathrm{mg} / \mathrm{L} \mathrm{F}^{-}$. To examine the stability of chromophoric complexes, solutions after color reaction were stored under room light illumination at $25^{\circ} \mathrm{C}$, dark at $25{ }^{\circ} \mathrm{C}$ or dark at $5{ }^{\circ} \mathrm{C}$, respectively.

\section{Chemical analysis}

Dissolved $\mathrm{Fe}^{2+}$ was measured by the 1,10-phenanthroline analytical method at $510 \mathrm{~nm}$ using a UV-Vis spectrophotometer (Tamura et al. 1974). Total iron concentrations were measured through the reduction of $\mathrm{Fe}^{3+}$ to $\mathrm{Fe}^{2+}$ by hydroxylamine $\mathrm{HCl}$. The concentration of $\mathrm{Fe}^{3+}$ was calculated as the difference in concentrations between total iron and $\mathrm{Fe}^{2+}$.

\section{Results and discussion}

\section{Analysis of the error of determination of $\mathrm{Fe}^{2+}$ in the presence of $\mathrm{Fe}^{3+}$}

The chromophoric complexes by 1,10-phenanthroline and high concentration of $\mathrm{Fe}^{3+}$ could increase the absorbance of samples at $510 \mathrm{~nm}$. To analyze the effect of $\mathrm{Fe}^{3+}$ on the measurement of $\mathrm{Fe}^{2+}$, different concentrations of $\mathrm{Fe}^{3+}$ were added to $2 \mathrm{mg} / \mathrm{L} \mathrm{Fe}^{2+}$ solution. The absorbance of solutions at $510 \mathrm{~nm}$ increased with the increase in concentrations of $\mathrm{Fe}^{3+}$, as shown in Fig. 1. The error reached $22.6 \%$ when the concentration of $\mathrm{Fe}^{3+}$ was 16 times more than that of $\mathrm{Fe}^{2+}$ which is common in AMD. The error was more than 50\% when $\mathrm{Fe}^{3+}$ was not complexed and $\mathrm{Fe}^{2+}$ was less than $1 \%$ of the total iron (Herrera et al. 1989). So, $\mathrm{Fe}^{3+}$ obviously affects the measurement of $\mathrm{Fe}^{2+}$ when the concentration of $\mathrm{Fe}^{3+}$ was more than that of $\mathrm{Fe}^{2+}$ in solution.

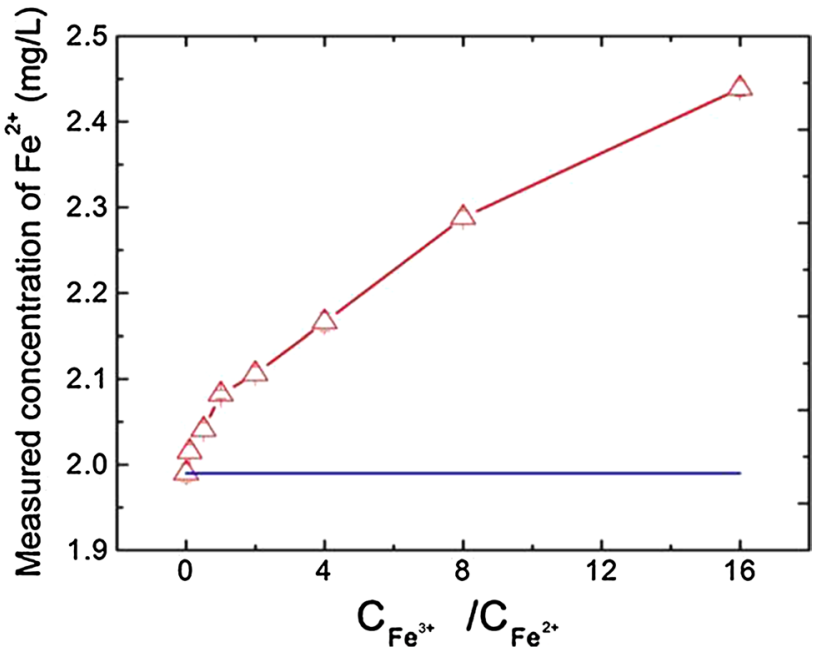

Fig. 1 Interference of $\mathrm{Fe}^{3+}$ on the measured concentration of $\mathrm{Fe}^{2+}$. $\mathrm{C}_{\mathrm{Fe}}^{3+} / \mathrm{C}_{\mathrm{Fe}}^{2+}$ was molar concentration ratio. Experimental conditions: $2 \mathrm{mg} / \mathrm{L} \mathrm{Fe}^{2+}$ and different concentrations of $\mathrm{Fe}^{3+}$

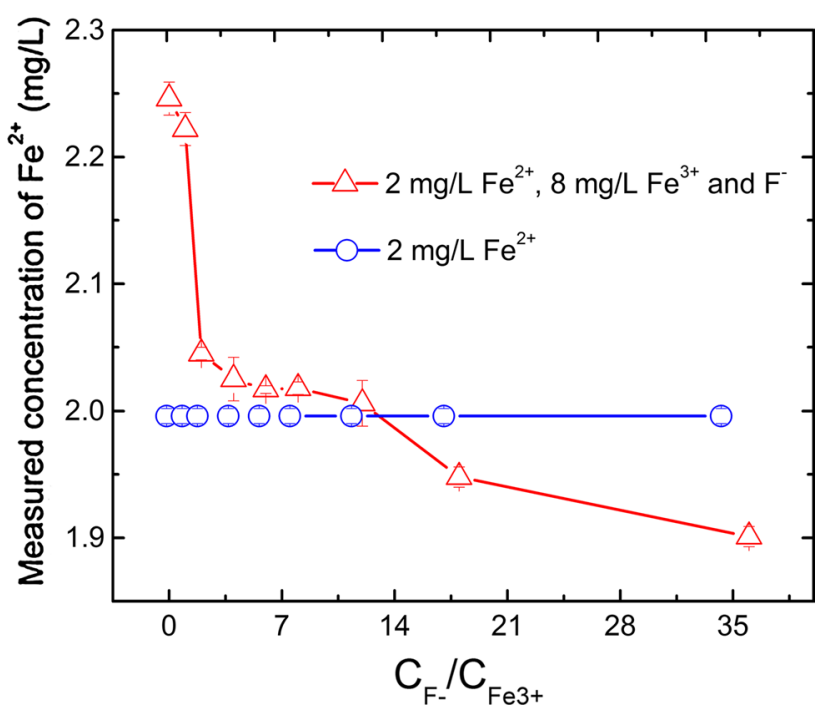

Fig. 2 Effect of dosage of $\mathrm{F}^{-}$on the determination of $\mathrm{Fe}^{2+}$ in the presence of $\mathrm{Fe}^{3+}$. Experimental conditions: $2 \mathrm{mg} / \mathrm{L} \mathrm{Fe}^{2+}, 8 \mathrm{mg} / \mathrm{L} \mathrm{Fe}^{3+}$ and with or without the addition of $\mathrm{F}^{-} ; \mathrm{C}_{\mathrm{F}}^{-} / \mathrm{C}_{\mathrm{Fe}}^{3+}$ was molar concentration ratio

\section{Determination of $\mathrm{F}^{-}$dosage}

The reaction of $\mathrm{F}^{-}$with $\mathrm{Fe}^{3+}$ formed ferric fluoride (Herrera et al. 1989) which could make interference of $\mathrm{Fe}^{3+}$, so $\mathrm{F}^{-}$was selected as the complexing agent to modify the 1,10-phenanthroline method (Muir and Andersen 1977). The effect of $\mathrm{F}^{-}$on the determination of $\mathrm{Fe}^{2+}$ in the presence of $\mathrm{Fe}^{3+}$ is shown in Fig. 2, where $2 \mathrm{mg} / \mathrm{L} \mathrm{Fe}^{2+}$ and $8 \mathrm{mg} / \mathrm{L} \mathrm{Fe}^{3+}$ were in solution. It should be noted that the absorbance of samples after chromogenesis decreased 
with the increase in concentrations of $\mathrm{F}^{-}$(Fig. 2). When $\mathrm{F}^{-} / \mathrm{Fe}^{3+}$ molar concentration ratio was from 1 to 2 , the errors of samples decreased quickly. And the errors of samples decreased slowly when $\mathrm{F}^{-} / \mathrm{Fe}^{3+}$ molar concentration ratio was from 2 to 12 . The $\mathrm{F}^{-}$could eliminate absolutely the effect of $\mathrm{Fe}^{3+}$ when $\mathrm{F}^{-} / \mathrm{Fe}^{3+}$ molar concentration ratio was 13.3(Fig. 2). But negative error was caused by excess $\mathrm{F}^{-}$(Fig. 2). So, the amount of $\mathrm{F}^{-}$depended on the $\mathrm{Fe}^{3+}$ concentrations in the sample. With less or more dosage of $\mathrm{F}^{-}$, the masking effect of $\mathrm{F}^{-}$was not best. The previous studies documented the error was decreasing with amount of $\mathrm{F}^{-}$(Leandro et al. 1989; Tamura et al. 1974), but Tamura et al. found that a large excess of $\mathrm{F}^{-}$has no effect on measurement of iron species (Tamura et al. 1974).

\section{Effect of temperature on reaction}

The temperature affects the chemical reaction ratio, but a few studies reported the effect of temperature on the 1,10phenanthroline method and masking action of $\mathrm{F}^{-}$(Anastácio et al. 2008; Leandro et al. 1989; Muir and Andersen 1977; Tamura et al. 1974). So we have evaluated the influence of temperature on color reaction and $\mathrm{F}^{-}$masking action. The solutions which contain $2 \mathrm{mg} / \mathrm{L} \mathrm{Fe}^{2+}, 8 \mathrm{mg} / \mathrm{L} \mathrm{Fe}^{3+}$ and with or without the addition of $\mathrm{F}^{-}$were stored under 5,15 and $30^{\circ} \mathrm{C}$, respectively. Figure 3 shows that temperature did not affect the masking action of $\mathrm{F}^{-}$, but affect significantly color reaction at $5-30{ }^{\circ} \mathrm{C}$. The color reaction finished within $15 \mathrm{~min}$, and the complexes from the reaction of $\mathrm{Fe}^{2+}$ with 1,10-phenanthroline kept stable within $1 \mathrm{~h}$ under $15-30{ }^{\circ} \mathrm{C}$. The color reaction finished at $45 \mathrm{~min}$ under $5{ }^{\circ} \mathrm{C}$. These suggested that color reaction needs more time at lower temperature. The experiment results of Herrera et al. (1989)

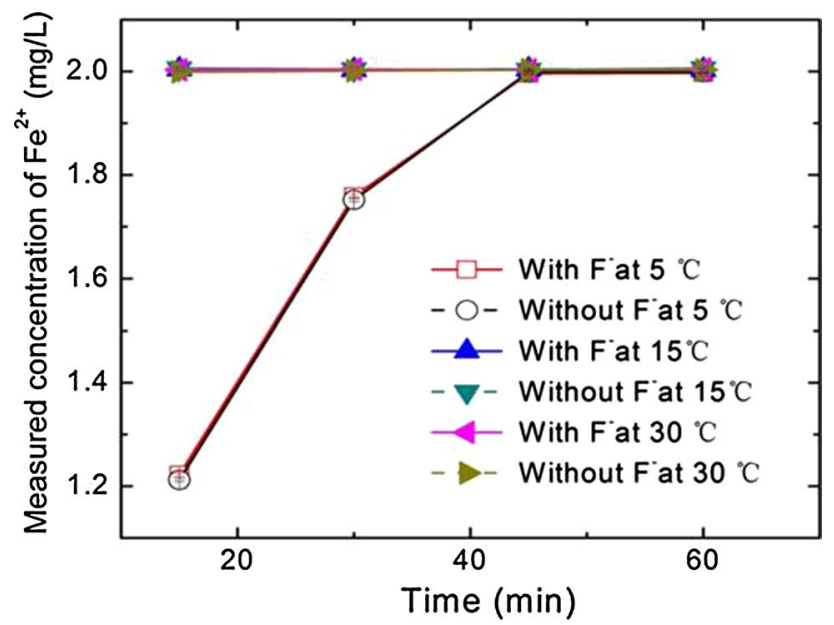

Fig. 3 Effect of temperature on the determination of $\mathrm{Fe}^{2+}$ in the presence of $\mathrm{Fe}^{3+}$. Experimental conditions: $2 \mathrm{mg} / \mathrm{L} \mathrm{Fe}^{2+}, 8 \mathrm{mg} / \mathrm{L} \mathrm{Fe}^{3+}$ and with or without the addition of $36.1 \mathrm{mg} / \mathrm{L} \mathrm{F}^{-}$under room light illumination show that the absorbance of solution increased after $5 \mathrm{~min}$ when all reagents were added at ambient temperature. The main reason may be that chromogenic reaction time was insufficient.

\section{Effect of storage condition}

To further evaluate the stability of chromophoric complexes, the solution with or without the addition of $\mathrm{F}^{-}$after color reaction was stored at different conditions. The chromophoric complex concentrations decreased with time (Fig. 4). The chromophoric complexes were stable within $2 \mathrm{~h}$ and decomposed $24.0 \%$ in $96 \mathrm{~h}$ under light illumination and $25{ }^{\circ} \mathrm{C}$. The chromophoric complexes were stable within $12 \mathrm{~h}$ and decomposed $6.3 \%$ in $96 \mathrm{~h}$ under dark and $25{ }^{\circ} \mathrm{C}$. The chromophoric complexes were stable within $24 \mathrm{~h}$ and decomposed $1.9 \%$ in $96 \mathrm{~h}$ under dark condition and $5{ }^{\circ} \mathrm{C}$. So, both light and temperature affected the stability of chromophoric complexes, and the effect of light on breaking chromophoric complexes was much greater than that of temperature. Because the absorbance of solutions with the addition of $\mathrm{F}^{-}$was consistent with that without the addition of $\mathrm{F}^{-}$, the light or temperature has not affected the masking action of $\mathrm{F}^{-}$, and $\mathrm{F}^{-}$had not affected the stability of chromophoric complexes. Verbeek (1961) found that the absorbance of solution increased because the Fe(III)-phen complex transformed Fe(II)-phen complex due to photoreduction when the solution was exposed to sunlight before the addition of $\mathrm{F}^{-}$. Our procedure was completed in reference to Herrera's procedure (Tamura et al. 1974), so the absorbance of solutions not increased with time. The solutions after chromogenesis should be kept in dark and low temperature before they were measured.

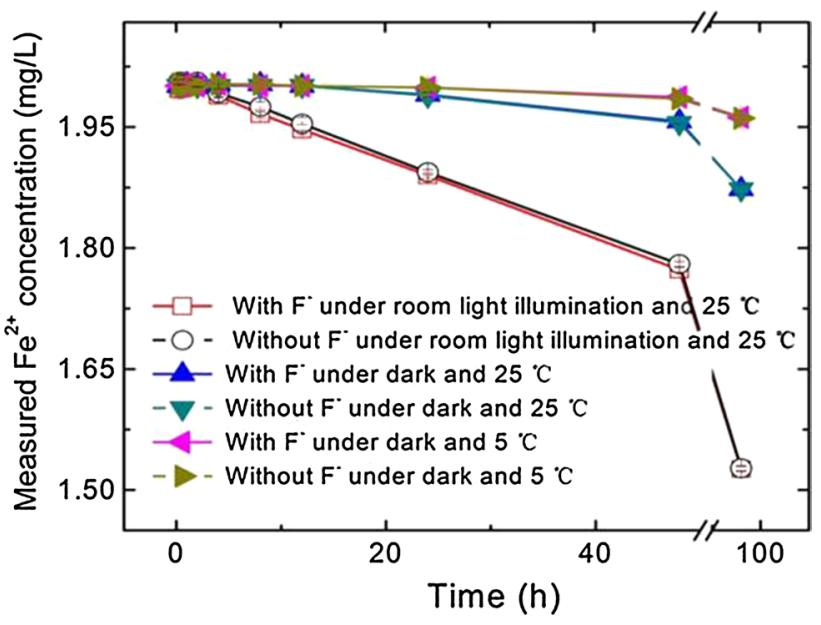

Fig. 4 Effect of light and temperature on chromophoric complexes. Experimental condition: solutions which contained $2 \mathrm{mg} / \mathrm{L} \mathrm{Fe}^{2+}$, $8 \mathrm{mg} / \mathrm{L} \mathrm{Fe}^{3+}$ and with or without the addition of $36.1 \mathrm{mg} / \mathrm{L} \mathrm{F}^{-}$after chromogenesis was kept under different lights or temperatures

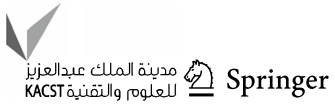




\section{Conclusion}

The high concentration $\mathrm{Fe}^{3+}$ in the sample interfered with the analysis of $\mathrm{Fe}^{2+}$ in the process of colorimetry by the 1,10-phenanthroline method. The previous studies modified spectrophotometric method which was based upon the addition of sodium fluoride to complex Fe(III) to eliminate interference (Leandro et al. 1989; Tamura et al. 1974). In this study, we found that $\mathrm{F}^{-}$could mask absolutely the interference of $\mathrm{Fe}^{3+}$ when $\mathrm{F}^{-} / \mathrm{Fe}^{3+}$ molar concentration ratio was 13.3. The low temperature reduces the rate of chromogenic reaction. The temperature or light did not affect the masking action of $\mathrm{F}^{-}$. Low temperature and dark conditions favored the stability of chromophoric complex. This method is available to exactly determine the iron species in AMD.

Acknowledgements This work was supported by the Natural Science Foundation of China (NSFC, No. 41763018), Program Foundation of Institute for Scientific Research of Karst Area of NSFC-GZGOV (No. U1612442), Fund of Guizhou for Construction of First-class Discipline in China (GNYL[2017]007) and the Science and Technology Foundation of Guizhou Province (No. (2018)1155).

Open Access This article is distributed under the terms of the Creative Commons Attribution 4.0 International License (http://creativeco mmons.org/licenses/by/4.0/), which permits unrestricted use, distribution, and reproduction in any medium, provided you give appropriate credit to the original author(s) and the source, provide a link to the Creative Commons license, and indicate if changes were made.

\section{References}

Amonette JE, Matyáš J (2016) Determination of ferrous and total iron in refractory spinels. Anal Chim Acta 910:25-35

Anastácio AS, Harris B, Yoo H-I, Fabris JD, Stucki JW (2008) Limitations of the ferrozine method for quantitative assay of mineral systems for ferrous and total iron. Geochim Cosmochim Acta 72:5001-5008

Arnold T, Baumann N, Krawczyk-Baersch E, Brockmann S, Zimmermann U, Jenk U, Weiss S (2011) Identification of the uranium speciation in an underground acid mine drainage environment. Geochim Cosmochim Acta 75:2200-2212

Blowes DW, Ptacek CJ, Jambor JL, Weisener CG (2003) The geochemistry of acid mine drainage. In: Rudnick RL (ed) Treatise on geochemistry. Elsevier Ltd, Amsterdam, pp 149-204

Clark LJ (1962) Iron(II) determination in the presence of iron(III) using 4,7-diphenyl-1,10-phenanthroline. Anal Chem 34:348-352

Gray NF (1998) Acid mine drainage composition and the implications for its impact on lotic systems. Water Res 32:2122-2134
Herrera L, Ruiz P, Aguillon JC, Fehrmann A (1989) A new spectrophotometric method for the determination of ferrous iron in the presence of ferric iron. J Chem Technol Biotechnol 44:171-181

Iakovleva E, Makila E, Salonen J, Sitarz M, Wang S, Sillanpaa M (2015) Acid mine drainage (AMD) treatment: neutralization and toxic elements removal with unmodified and modified limestone. Ecol Eng 81:30-40

Leandro H, Pauline R, Aguillon JC, Alexis F (1989) A new spectrophotometric method for the determination of ferrous iron in the presence of ferric iron. J Chem Technol Biotechnol 44:171-181

Matlock MM, Howerton BS, Atwood DA (2002) Chemical precipitation of heavy metals from acid mine drainage. Water Res 36:4757-4764

Moss ML, Mellon MG (1942) Colorimetric determination of iron with 2,2'-bipyridyl and with 2,2',2'-terpyridyl. Ind Eng Chem Anal Ed 14:862-865

Muir MK, Andersen TN (1977) Determination of ferrous iron in copper-process metallurgical solutions by the $o$-phenanthroline colorimetric method. Metall Trans B 8:517-518

Nordstrom DK, Alpers CN, Ptacek CJ, Blowes DW (2000) Negative pH and extremely acidic mine waters from Iron Mountain, California. Environ Sci Technol 34:254-258

Sumitomo T, Osaki M, Ogusu T, Takeuchi M, Tanaka H (2017) Internal standard-amplitude modulated multiplexed flow analysis. Anal Sci 33(12): 1363-1368

Tamura H, Goto K, Yotsuyanagi T, Nagayama M (1974) Spectrophotometric determination of iron(II) with 1,10-phenanthroline in the presence of large amounts of iron(III). Talanta 21:314-318

Tong M, Yuan S, Ma S, Jin M, Liu D, Cheng D, Liu X, Gan Y, Wang Y (2016) Production of abundant hydroxyl radicals from oxygenation of subsurface sediments. Environ Sci Technol 50(1):214-221

Tutu H, McCarthy TS, Cukrowska E (2008) The chemical characteristics of acid mine drainage with particular reference to sources, distribution and remediation: the Witwatersrand Basin, South Africa as a case study. Appl Geochem 23:3666-3684

Verbeek F (1961) Dosage Spectrophotométrique du Fer Ferreux en Présence D'un Excès de fer Ferrique, et du fer Ferrique En Présence D'Un Excès De Fer Ferreux. Bull Soc Chim Belg 70:423-434

Webb JA, Sasowsky ID (1994) The interaction of acid mine drainage with a carbonate terrane: evidence from the Obey River, NorthCentral Tennessee. J Hydrol 161:327-346

Wu P, Tang C, Liu C, Zhu L, Pei T, Feng L (2009) Geochemical distribution and removal of $\mathrm{As}, \mathrm{Fe}, \mathrm{Mn}$ and $\mathrm{Al}$ in a surface water system affected by acid mine drainage at a coalfield in Southwestern China. Environ Geol 57:1457-1467

Zhu J, Zhang P, Yuan S et al (2017) Production of hydroxyl radicals from oxygenation of simulated $\mathrm{AMD}$ due to $\mathrm{CaCO}_{3}$-induced $\mathrm{pH}$ increase. Water Res 111:118-126

Publisher's Note Springer Nature remains neutral with regard to jurisdictional claims in published maps and institutional affiliations. 